\title{
Effects of a benidipine-based combination therapy on the risk of stroke according to stroke subtype: the COPE trial
}

\author{
Seiji Umemoto ${ }^{1}$, Toshio Ogihara ${ }^{2,3}$, Hiromi Rakugi ${ }^{3}$, Masayasu Matsumoto ${ }^{4}$, Kazuo Kitagawa ${ }^{5}$, \\ Kazuyuki Shimada ${ }^{6}$, Jitsuo Higaki ${ }^{7}$, Sadayoshi Ito ${ }^{8}$, Hiromichi Suzuki ${ }^{9}$, Yasuo Ohashi ${ }^{10}$, Takao Saruta ${ }^{11}$ and \\ Masunori Matsuzaki ${ }^{12}$, on behalf of the Combination Therapy of Hypertension to Prevent Cardiovascular \\ Events Trial Group
}

The Combination Therapy of Hypertension to Prevent Cardiovascular Events (COPE) trial compared the dihydropyridine T/L-type calcium channel blocker benidipine-based therapies when combined with an angiotensin receptor blocker (ARB), a $\beta$-blocker (BB) or a thiazide diuretic (TD). The results suggested that benidipine combined with a BB appeared to be less beneficial in reducing the risk of stroke compared with the benidipine-TD combination (hazard ratio (HR): $2.31, P=0.0109$ ). We further evaluated the treatment effects on different stroke subtypes among the three benidipine-based regimens. The COPE trial was an investigator-initiated, multicenter study with PROBE design. Patients with atrial fibrillation or flutter were excluded from the study. All stroke events were subclassified with the Trial of Org 10172 in Acute Stroke Treatment (TOAST) criteria. The total incidence of stroke was 4.7, hemorrhagic stroke was 1.6 and ischemic stroke was 2.5 per 1000 person-years. The incidence of lacunar stroke was 1.1 , large-artery stroke was 0.6 , cardioembolic stroke was 0.3 , unknown ischemic type was 0.6 and transient ischemic attack was 0.6 per 1000 person-years. Although few differences in stroke subtypes were observed among the three treatment groups, multi-adjusted HRs for the incidence rates of all types of stroke, hemorrhagic stroke and ischemic stroke were significantly higher with the benidipine-BB regimen than with the benidipine-TD regimen. The incidence of both hemorrhagic and ischemic stroke in the benidipine-ARB regimen was not different compared with the other two treatment regimens. This prespecified sub-analysis suggested that a blood pressure-lowering therapy with a benidipine-TD regimen might be beneficial for hypertensive patients to prevent both hemorrhagic and ischemic stroke.

Hypertension Research (2013) 36, 1088-1095; doi:10.1038/hr.2013.100; published online 29 August 2013

Keywords: adrenergic $\beta$-antagonists; angiotensin antagonists; antihypertensive therapy/diuretics; calcium channel blockers; stroke

\section{INTRODUCTION}

Several prospective cohort studies of cardiovascular disease demonstrated that high sodium intake was associated with an increased risk of stroke, independent of vascular risk factors, ${ }^{1}$ and that strokes are preponderant cardiovascular events in some regions and countries, including Japan. ${ }^{2-6}$ However, it is well established that antihypertensive treatment reduces cardiovascular morbidity and mortality, especially stroke. ${ }^{7-9}$ The incidence of ischemic stroke, particularly lacunar stroke, in the overall Japanese population has declined significantly over the past 40 years, ${ }^{9}$ most likely due to the improved management of hypertension aimed at controlling blood pressure (BP) to $<140 / 90 \mathrm{~mm} \mathrm{Hg}^{7-9}$ In contrast, the incidence of large-artery stroke has remained steady in the younger population, ${ }^{10}$ most likely due to the insufficient control of hypertension and the increase in metabolic disorders. ${ }^{2}$

The reduction in systolic BP mainly explained cardiovascular outcomes, and the differences among antihypertensive drug classes are quite small compared with the benefits of maximizing the reduction in BP. Dihydropyridine calcium channel blockers (CCBs) might offer a selective benefit in the prevention of stroke. ${ }^{11,12}$ Thus, recent recommendations focused on building effective drug combinations rather than on which drug to use. ${ }^{13,14}$ The Combination

${ }^{1}$ Center for Clinical Research, Yamaguchi University Hospital, Ube, Japan; ${ }^{2}$ Morinomiya University of Medical Sciences, Osaka, Japan; ${ }^{3}$ Department of Geriatric Medicine and Nephrology, Osaka University Graduate School of Medicine, Suita, Japan; ${ }^{4}$ Department of Clinical Neuroscience and Therapeutics, Hiroshima University Graduate School of Medicine, Hiroshima, Japan; ${ }^{5}$ Department of Neurology, Stroke Center, Osaka University Graduate School of Medicine, Suita, Japan; ${ }^{6}$ Shin-Oyama City Hospital, Oyama, Japan; ${ }^{7}$ Department of Integrated Medicine and Informatics, Ehime University Graduate School of Medicine, Toon, Japan; ${ }^{8}$ Division of Nephrology, Department of Medicine, Oyama, Tohoku University, School of Medicine, Sendai, Japan; ${ }^{9}$ Department of Nephrology, Saitama Medical University, Iruma, Japan; ${ }^{10}$ Department of Biostatistics, School of Public Health, University of Tokyo, Tokyo, Japan; ${ }^{11}$ Keio University, Tokyo, Japan and ${ }^{12}$ Yamaguchi University, Ube, Japan

Correspondence: Dr S Umemoto, Center for Clinical Research, Yamaguchi University Hospital, 1-1-1 Minami-Kogushi, Ube, Yamaguchi 755-8505, Japan.

E-mail: umemoto@yamaguchi-u.ac.jp

Received 19 January 2013; revised 16 May 2013; accepted 27 May 2013; published online 29 August 2013 
Therapy of Hypertension to Prevent Cardiovascular Events (COPE) trial is the first clinical trial to examine combination therapy with benidipine, a potent and long-acting dihydropyridine CCB that inhibits not only L-type and N-type calcium channels but also T-type calcium channels ${ }^{15}$ for the treatment of hypertension in Japan. The trial results demonstrated that although the percentage of subjects achieving the target $\mathrm{BP}$ and the incidence of primary composite cardiovascular end points were similar among the benidipine-thiazide diuretic (TD), benidipine-angiotensin receptor blocker (ARB) and benidipine- $\beta$-blocker (BB) groups, second analyses suggested that benidipine combined with a $\mathrm{BB}$ appeared to be less beneficial in reducing the risk of stroke compared with the benidipine-thiazide combination, predominantly in the elderly. ${ }^{16-18}$

Although all benidipine-based regimens were well tolerated, the following adverse events were more frequent than in the other groups: new-onset diabetes and bradycardia in the benidipine-BB group; hyperuricemia, hypokalemia and increased levels of serum creatinine in the benidipine-thiazide group; hyperkalemia in the benidipine$\mathrm{ARB}$ group; vertigo in the benidipine- $\mathrm{BB}$ and benidipine-thiazide groups; and increased levels of alanine aminotransferase in the benidipine-ARB and benidipine-thiazide groups. ${ }^{17}$

It remains unknown which benidipine-based combination therapy was valuable for preventing the occurrence of specific types of stroke during treatment for hypertension in the COPE trial. Thus, in this prespecified, post hoc analysis of the COPE trial, we further evaluated the treatment effects of different stroke subtypes among the three benidipine-based regimens.

\section{METHODS}

\section{Study design, setting and participants}

The COPE trial was an investigator-initiated, multicenter study with PROBE design that compared cardiovascular effects and achievement of the target BP $(<140 / 90 \mathrm{~mm} \mathrm{Hg})$ with three dihydropyridine CCB benidipine-based regimens (ARB, BB or thiazide) in 3501 hypertensive patients who had not achieved the target $\mathrm{BP}$ with benidipine at a dose of $4 \mathrm{mg} \mathrm{day}^{-1}$. The rationale, design, trial management and results of the COPE trial have previously been reported. ${ }^{16-18}$ In brief, participants with a sitting systolic BP of $140 \mathrm{~mm} \mathrm{Hg}$ or more and/or a diastolic BP of $90 \mathrm{~mm} \mathrm{Hg}$ or more, whether untreated or treated, were men and women aged 40 to 85 years who did not achieve the target BP in a sitting position at our clinic following monotherapy with benidipine at a dose of $4 \mathrm{mg} \mathrm{day}^{-1}$ during the run-in phase (4-8 weeks). These patients were randomly assigned to receive benidipine combined with an ARB, a $\mathrm{BB}$ or a thiazide. After the randomization, all patients were followed for at least 3 years until the trial was terminated. The BP management titration algorithm, together with other details of the study design, has been previously described. ${ }^{16,17}$ The median follow-up period was 3.6 years. ${ }^{17}$

\section{Definitions and classification}

A prespecified, post hoc analysis of the subtype of strokes was made to compare the cardiovascular effects of benidipine-based combination regimens (benidipine-ARB vs. benidipine-BB vs. benidipine-thiazide). The evaluated stroke events (all types) were consistent with the original trial design and included the primary and secondary end points of the COPE trial. ${ }^{16}$

Stroke and transient ischemic attack were defined using the World Health Organization criteria, as reported previously. ${ }^{19}$ The baseline cerebrovascular event was defined by investigators as the previous cerebrovascular event, using evidence from the medical history and physical examination that was supplemented by clinical records and/or radiological findings, if available (computed tomography and/or magnetic resonance imaging). All follow-up strokes were subclassified whenever possible as ischemic stroke, hemorrhagic stroke or unknown type. During follow-up, the Trial of Org 10172 in Acute Stroke Treatment (TOAST) criteria were used to further subclassify ischemic stroke recorded as lacunar stroke, cardioembolic stroke, large-artery stroke or unknown ischemic type. ${ }^{20}$ All suspected stroke outcome events and adverse events related to cerebrovascular events recorded during follow-up were first reviewed and reported by the relevant local study investigator. Events were then evaluated by the Independent Endpoint Classification Committee, which included two neurologists, and all potential cases were provided with a clinical summary of the event and copies of available investigation reports and films, before and after the event (for example, biochemistry, hematology, computed tomography and/or magnetic resonance imaging including diffusion-weighted image and magnetic resonance angiography, carotid ultrasound and electrocardiogram).

\section{Statistical methods}

In total, 3293 patients (1110, benidipine-ARB; 1089, benidipine-BB and 1094, benidipine-thiazide) were prescribed a combination treatment and compared with the full set analysis to specifically evaluate the benidipine-based combination therapy for hypertension in the COPE trial. ${ }^{17}$ Patient characteristics were reported as the mean \pm s.d. or percentage. Continuous variables were compared with Student's $t$-tests or one-way analysis of variance, as appropriate. Categorical variables were compared with the $\chi^{2}$ test. Survival curves were generated by the Kaplan-Meier method for hemorrhagic or ischemic stroke among the three treatment groups. Survival curves were compared using the log-rank test. Hazard ratios (HRs) and confidence intervals (CIs) were calculated using the Cox proportional hazards model. All data were analyzed using SAS System Release 9.1 software (SAS Institute, Cary, NC, USA). All reported $P$-values are two-sided.

\section{RESULTS}

Demographic and baseline patient characteristics of the COPE trial Demographic and baseline patient characteristics of the COPE trial are shown in Table 1. Among the 3293 patients in the COPE trial, the baseline characteristics, including the previous history of cerebrovascular disease and need for anti-platelet/anti-coagulation therapy, were well matched among those randomized to the three regimens (Table 1). Detailed information on the studied drugs has been provided elsewhere. ${ }^{17}$ In addition, no apparent differences were observed in the concomitant medication usage throughout the study (Supplementary Table S1).

\section{BP control during the treatment}

The reduction in BP from baseline was similar among the three treatment groups over the course of the trial. ${ }^{17}$ In addition, at the end of treatment, the percentage of patients who achieved the target BP did not differ among the three treatment groups (Supplementary Table S2).

Occurrence of atrial fibrillation or atrial flutter during follow-up A total of 19 atrial fibrillation or atrial flutter occurrences were reported as adverse events during the study (benidipine-ARB group: 4 atrial fibrillation and 1 atrial flutter; benidipine-BB group: 8 atrial fibrillation; benidipine-thiazide group: 6 atrial fibrillation), and there were no significant differences in the occurrence of atrial fibrillation or atrial flutter among the three treatment groups $(P=0.671)$.

Occurrence of stroke and stroke subtypes during follow-up During the study, 80 cerebrovascular events were reviewed by the Independent Endpoint Classification Committee, and a total of 56 strokes were confirmed as cerebrovascular events (Table 2). The classification of stroke subtype was based on radiographic, electrocardiographic, and carotid and cardiac ultrasound evidence. The Independent Endpoint Classification Committee further reviewed 23 possible stroke events that were not confirmed as strokes. 
Table 1 Demographic and baseline characteristics of the study patients

\begin{tabular}{|c|c|c|c|}
\hline & $\begin{array}{l}\text { Benidipine plus } \\
\text { ARB }(\mathrm{n}=1110)\end{array}$ & $\begin{array}{l}\text { Benidipine plus } \\
B B(\mathrm{n}=1089)\end{array}$ & $\begin{array}{l}\text { Benidipine plus } \\
T D(\mathrm{n}=1094)\end{array}$ \\
\hline \multicolumn{4}{|l|}{ Demographic } \\
\hline Sex, male & 566 (51.0\%) & 550 (50.5\%) & 553 (50.5\%) \\
\hline Age, years & $63.0 \pm 10.6$ & $63.2 \pm 10.8$ & $63.1 \pm 10.8$ \\
\hline \multicolumn{4}{|l|}{ Baseline characteristics } \\
\hline $\mathrm{BMI}, \mathrm{kg} \mathrm{m}^{-2}$ & $24.6 \pm 3.4$ & $24.6 \pm 3.4$ & $24.4 \pm 3.4$ \\
\hline Systolic BP, mm Hg & $153.9 \pm 11.8$ & $153.7 \pm 10.9$ & $154.1 \pm 12.0$ \\
\hline Diastolic BP, mm Hg & $89.0 \pm 9.8$ & $88.7 \pm 9.6$ & $88.7 \pm 9.8$ \\
\hline Heart rate, beat $\mathrm{min}^{-1}$ & $74.0 \pm 11.0$ & $74.2 \pm 11.1$ & $74.2 \pm 11.5$ \\
\hline \multicolumn{4}{|l|}{ Risk factors } \\
\hline $\begin{array}{l}\text { Previous cardio- } \\
\text { vascular disease }\end{array}$ & $144(13.0 \%)$ & $124(11.4 \%)$ & $137(12.5 \%)$ \\
\hline $\begin{array}{l}\text { Previous cerebro- } \\
\text { vascular disease }\end{array}$ & $50(4.5 \%)$ & $36(3.3 \%)$ & $40(3.7 \%)$ \\
\hline Diabetes & $154(13.9 \%)$ & $155(14.2 \%)$ & $157(14.4 \%)$ \\
\hline Dyslipidemia & $429(38.6 \%)$ & $423(38.8 \%)$ & $454(41.5 \%)$ \\
\hline Current smoking & $436(39.3 \%)$ & $431(39.6 \%)$ & 435 (39.8\%) \\
\hline \multicolumn{4}{|l|}{ Previous medication } \\
\hline Antihypertensive agents & $891(80.3 \%)$ & $869(79.8 \%)$ & 872 (79.7\%) \\
\hline Benidipine & $698(62.9 \%)$ & $694(63.7 \%)$ & $691(63.2 \%)$ \\
\hline Other $\mathrm{CCB}$ & $129(11.6 \%)$ & $115(10.6 \%)$ & $120(11.0 \%)$ \\
\hline ARB & $103(9.3 \%)$ & $103(9.5 \%)$ & $98(9.0 \%)$ \\
\hline ACE inhibitor & $20(1.8 \%)$ & $23(2.1 \%)$ & $14(1.3 \%)$ \\
\hline $\mathrm{BB}$ & $26(2.3 \%)$ & $38(3.5 \%)$ & $35(3.2 \%)$ \\
\hline Diuretics & $12(1.1 \%)$ & $8(0.7 \%)$ & $13(1.2 \%)$ \\
\hline Others & $10(0.9 \%)$ & $10(0.9 \%)$ & $3(0.3 \%)$ \\
\hline \multicolumn{4}{|l|}{ Concomitant medication } \\
\hline Anti-platelets & 99 ( $8.9 \%)$ & $74(6.8 \%)$ & $80(7.3 \%)$ \\
\hline Anticoagulants & $4(0.4 \%)$ & $2(0.2 \%)$ & $4(0.4 \%)$ \\
\hline Lipid-lowering agents & $234(21.1 \%)$ & $222(20.4 \%)$ & $232(21.2 \%)$ \\
\hline Statin & $189(17.0 \%)$ & $185(17.0 \%)$ & $178(16.3 \%)$ \\
\hline Antidiabetic agents & $77(6.9 \%)$ & $80(7.3 \%)$ & $79(7.2 \%)$ \\
\hline
\end{tabular}

Abbreviations: $A C E$, angiotensin-converting enzyme; $A R B$, angiotensin receptor blocker; $B B$, $\beta$-blocker; BMI, body-mass index; BP, blood pressure; CCB, calcium channel blocker; TD, thiazide diuretic.

Data are shown as number of patients $(\%)$ or mean \pm s.d.

The Committee also made reclassifications for 14 cases among stroke subtypes. The classification of strokes was reported as: one lacunar stroke to large-artery stroke, one lacunar stroke to unknown ischemic type, three large-artery strokes to lacunar stroke, four large-artery strokes to unknown ischemic type, one cardioembolic stroke to unknown ischemic type, one unknown ischemic type to lacunar stroke, one large-artery stroke with lacunar stroke to large-artery stroke, one large-artery stroke with transient ischemic attack to unknown ischemic type and one transient ischemic attack to lacunar stroke.

As a result of the review by the Committee, the total incidence of stroke in the COPE trial was 4.7, including 1.6 hemorrhagic strokes and 2.5 ischemic strokes per 1000 person-years. In addition, the incidence of lacunar stroke was 1.1, large-artery stroke was 0.6, cardioembolic stroke was 0.3 , unknown ischemic type was 0.6 and transient ischemic attack was 0.6 per 1000 person-years. As shown in Table 2 and Figure 1, although the incidence of all types of stroke was
Table 2 Incidence of all types of stroke, hemorrhagic stroke and ischemic stroke

\begin{tabular}{|c|c|c|c|c|c|}
\hline & $\begin{array}{c}\text { Total } \\
(\mathrm{n}=3293)\end{array}$ & $\begin{array}{l}\text { Benidipine } \\
\text { plus ARB } \\
(\mathrm{n}=1110)\end{array}$ & $\begin{array}{c}\text { Benidipine } \\
\text { plus } B B \\
(\mathrm{n}=1089)\end{array}$ & $\begin{array}{c}\text { Benidipine } \\
\text { plus TD } \\
(n=1094)\end{array}$ & $\begin{array}{c}\text { P-value } \\
\text { Log- } \\
\text { rank }\end{array}$ \\
\hline $\begin{array}{l}\text { All types of } \\
\text { stroke }\end{array}$ & $56(4.7)$ & $17(4.2)$ & $27(7.0)$ & $12(3.0)$ & 0.0326 \\
\hline $\begin{array}{l}\text { Hemorrhagic } \\
\text { stroke }\end{array}$ & $19(1.6)$ & $8(1.9)$ & $9(2.5)$ & $2(0.5)$ & 0.1001 \\
\hline $\begin{array}{l}\text { Intracerebral } \\
\text { hemorrhage }\end{array}$ & $17(1.4)$ & $6(1.4)$ & $9(2.5)$ & $2(0.5)$ & 0.1035 \\
\hline $\begin{array}{l}\text { Subarachnoid } \\
\text { hemorrhage }\end{array}$ & $2(0.2)$ & $2(0.5)$ & $0(0)$ & $0(0)$ & 0.1444 \\
\hline Ischemic stroke & $30(2.5)$ & $9(2.2)$ & $15(3.9)$ & $6(1.5)$ & 0.1046 \\
\hline Lacunar stroke & $13(1.1)$ & $5(1.2)$ & $6(1.5)$ & $2(0.7)$ & 0.3606 \\
\hline $\begin{array}{l}\text { Large-artery } \\
\text { stroke }\end{array}$ & $7(0.6)$ & $0(0)$ & $5(1.5)$ & $2(0.5)$ & 0.0608 \\
\hline $\begin{array}{l}\text { Cardioembolic } \\
\text { stroke }\end{array}$ & $3(0.3)$ & $1(0.2)$ & $2(0.5)$ & $0(0)$ & 0.3601 \\
\hline $\begin{array}{l}\text { Unknown } \\
\text { ischemic type }\end{array}$ & $7(0.6)$ & $3(0.7)$ & $2(0.5)$ & $2(0.5)$ & 0.8879 \\
\hline $\begin{array}{l}\text { Transient } \\
\text { ischemic attack }\end{array}$ & $7(0.6)$ & $0(0)$ & $3(0.7)$ & $4(1.0)$ & 0.1497 \\
\hline
\end{tabular}

Abbreviations: ARB, angiotensin receptor blocker; BB, $\beta$-blocker; TD, thiazide diuretic. Data are shown as incidence number (per 1000 person-years).

significantly higher in the benidipine-BB group than in the benidipine-thiazide group, the incidence of intracerebral hemorrhage or lacunar stroke was higher in the benidipine-ARB or benidipinethiazide group. The incidence of large-artery stroke was higher in the benidipine-BB group compared with the other two groups, and the incidence of transient ischemic attack of the benidipine-BB group and the benidipine-thiazide group was higher compared with the benidipine-ARB group. Few differences in each stroke subtype were observed among the three treatment groups.

HRs for all types of stroke, hemorrhagic stroke and ischemic stroke Figure 1 presents the unadjusted and multi-adjusted HRs for all types of stroke, hemorrhagic stroke and ischemic stroke in the three treatment groups of the COPE trial. As previously reported, ${ }^{17}$ the incidence of all types of stroke was higher with the benidipine-BB regimen than with the benidipine-thiazide regimen. Although few differences in the incidence of stroke subtypes were observed among the three treatment groups in this sub-analysis (Table 2), the incidence of hemorrhagic stroke and ischemic stroke was higher with the benidipine-BB regimen than with the benidipine-thiazide regimen. The incidence of all types of stroke, as well as hemorrhagic stroke and ischemic stroke, with the benidipine-ARB regimen did not differ from that of the other two treatment regimens.

Figure 1 also presents the unadjusted and adjusted HRs for systolic $\mathrm{BP}$ as a time-dependent covariate for all types of stroke, hemorrhagic stroke and ischemic stroke in the three treatment groups of the COPE trial. The unadjusted and adjusted HRs for systolic BP as a timedependent covariate of all types of stroke were higher with the benidipine- $\mathrm{BB}$ regimen than with the benidipine-thiazide regimen. The unadjusted and adjusted HRs for systolic BP as a time-dependent covariate of hemorrhagic stroke and ischemic stroke were also higher with the benidipine- $\mathrm{BB}$ regimen than with the benidipine-thiazide regimen. The unadjusted and adjusted HRs for systolic BP as a 


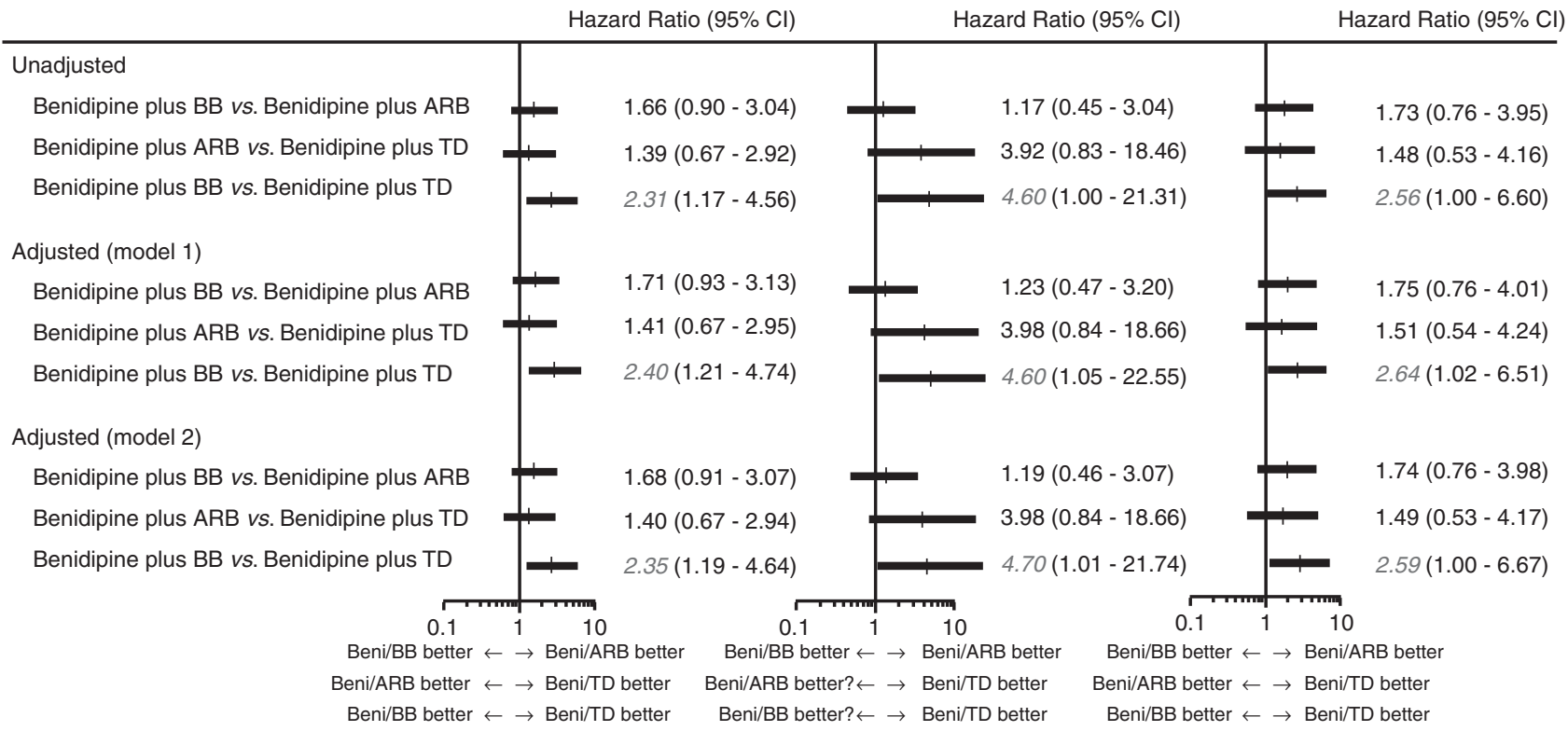

Figure 1 Hazard ratios for all types of stroke, hemorrhagic stroke and ischemic stroke in the three treatment groups. Model 1: hazard ratios were adjusted by sex, age, body mass index, systolic blood pressure at baseline, previous history of cerebral events, diabetes, dyslipidemia and prescription of antiplatelets. Model 2: hazard ratios were adjusted for systolic blood pressure as a time-dependent covariate. Hemorrhagic stroke: intracerebral hemorrhage and subarachnoid hemorrhage; ischemic stroke: lacunar stroke, large-artery stroke, cardioembolic stroke and unknown ischemic type. ARB, angiotensin receptor blocker; Beni, benidipine; $\mathrm{BB}, \beta$-blocker; $\mathrm{Cl}$, confidence interval; TD, thiazide diuretic. Italic entries indicate significant differences in the hazard ratio between the two treatment regimens. A full color version of this figure is available at the Hypertension Research journal online.

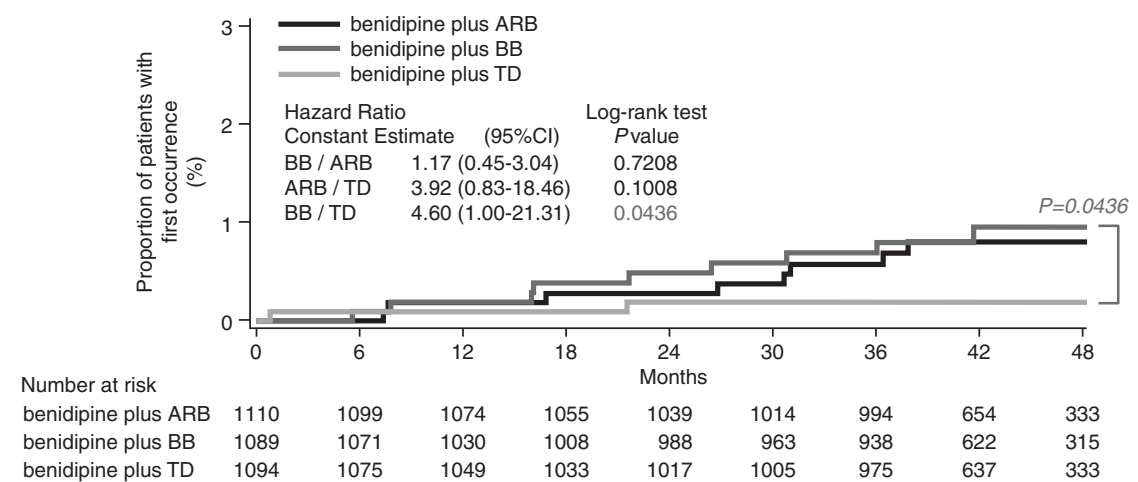

Figure 2 Kaplan-Meier curves for time to first hemorrhagic stroke in the three treatment groups. Hemorrhagic stroke: intracerebral hemorrhage and subarachnoid hemorrhage. ARB, angiotensin receptor blocker; $\mathrm{BB}, \beta$-blocker; $\mathrm{Cl}$, confidence interval; TD, thiazide diuretic. A full color version of this figure is available at the Hypertension Research journal online.

time-dependent covariate of all types of stroke, as well as hemorrhagic stroke and ischemic stroke, with the benidipine-ARB regimen did not differ from those of the other two treatment regimens.

\section{Hemorrhagic stroke in the three treatment groups}

Figure 2 shows the survival curves for time to first hemorrhagic stroke in the three treatment groups of the COPE trial. Although the incidence of hemorrhagic stroke was relatively low in the COPE trial, the incidence of hemorrhagic stroke was significantly higher in the benidipine-BB group than in the benidipine-thiazide group. It did not differ between the benidipine-ARB group and the other two treatment groups, although the incidence of hemorrhagic stroke in the benidipine-ARB group was relatively higher compared with that of the benidipine-thiazide group.
Ischemic stroke in the three combination treatment groups

Figure 3 shows the survival curves for time to first ischemic stroke in the three treatment groups of the COPE trial. Compared with the benidipine-thiazide group, the incidence of ischemic stroke was significantly higher in the benidipine-BB group, whereas it did not differ between the benidipine-ARB group and the other two treatment groups (Figure 3).

\section{DISCUSSION}

Hypertension is a major cause of cardiovascular disease, especially stroke. ${ }^{2-6}$ High sodium intake is associated with an increased risk of stroke, independent of vascular risk factors, ${ }^{1}$ and strokes are the preponderant cardiovascular events in some regions and countries, including Japan..$^{2-6}$ The previous meta-analysis showed that the reduction in systolic BP largely explained cardiovascular outcomes, 


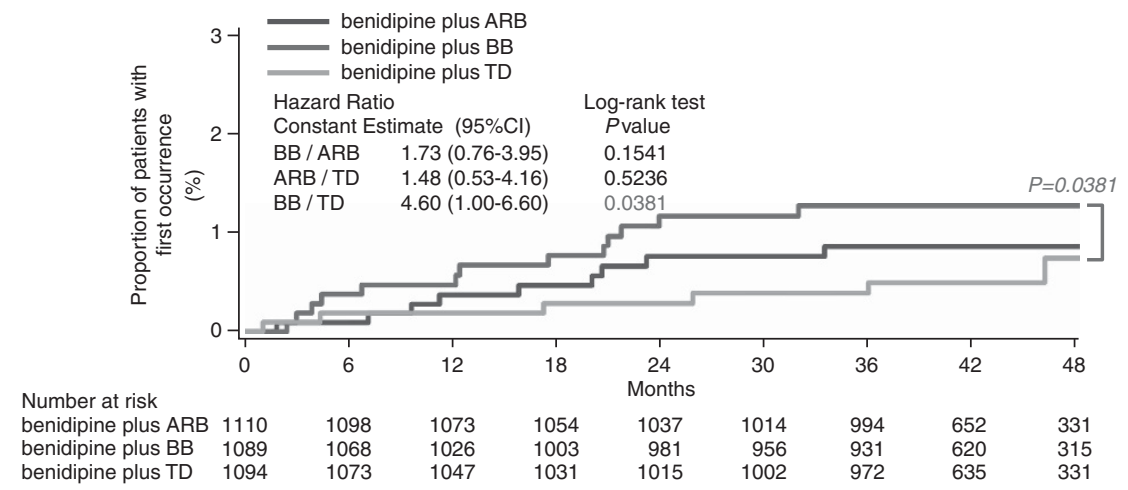

Figure 3 Kaplan-Meier curves for time to first ischemic stroke in the three treatment groups. Ischemic stroke: lacunar stroke, large-artery stroke, cardioembolic stroke and unknown ischemic type. ARB, angiotensin receptor blocker; BB, $\beta$-blocker; $\mathrm{Cl}$, confidence interval; TD, thiazide diuretic. A full color version of this figure is available at the Hypertension Research journal online.

and preventive effects against coronary heart disease were similar in different classes of antihypertensive drugs, whereas BBs were worse in preventing stroke than the other classes of antihypertensive drugs, including CCBs. ${ }^{21}$ The results of the COPE trial have shown that even in the CCB-based combination therapy of hypertension, BBs may not have any benefits over TDs and may even increase the risk of stroke, indicating that the use of BBs as combination therapy with CCBs may be challenging for hypertensive patients.

We have shown that both the reduction in BP from the baseline over the course of the trial and the percentage of patients who achieved the target BP by the end of treatment did not differ among the three randomized groups, including this sub-analysis of the COPE trial. However, the incidence of stroke was significantly higher with BBs compared with TDs. ${ }^{17}$ In the COPE trial, the incidence of stroke was relatively low, suggesting that benidipine-based treatment for hypertension may be beneficial for the prevention of stroke. This effect is most likely due to the T-type and L-type dihydropyridine calcium channel-blocking action of benidipine compared with other CCB-based treatments. ${ }^{15,22,23}$ However, this explanation should be supported by the comparison of risk profiles and on-treatment BP values of study subjects from different studies.

It was reported that T/L-type CCB benidipine inhibited aldosterone production. $^{24}$ It also directly inhibited the aldosterone-induced mineralocorticoid receptor activation ${ }^{25}$ and exerted a sodium diuretic action via T-type calcium channel inhibition. ${ }^{26}$ Therefore, this dual blocking action of the L-type and T-type calcium channels of benidipine might have exerted favorable effects in combination with a TD for the prevention of stroke in the COPE trial. In addition, TDs reduce arterial pressure initially through a fall in plasma volume and cardiac output, and their long-term pressure reduction is mediated through a reduction in total peripheral resistance. ${ }^{27}$ Furthermore, it was recently reported that compared with other drugs, interindividual variation in systolic BP was significantly reduced by $\mathrm{CCBs}$ and non-loop diuretic drugs but significantly increased by $\mathrm{ARB}$ and $\mathrm{BBs}{ }^{28}$

Furthermore, it has been reported that the use of a high dose of a $\mathrm{CCB}$ alone, or in combination with other agents, is likely to be particularly effective in preventing stroke, ${ }^{28}$ and it is important to note that the drug-class effects on interindividual variation in BP can account for differences in the effects of antihypertensive drugs on the risk of stroke, independent of the effects on the mean systolic BP. ${ }^{29,30}$ Differences of the CCB amlodipine and the BB atenolol in central aortic pressures are a potential mechanism to explain the different clinical outcomes between the two BP treatment arms. ${ }^{31}$ In addition, the LIFE study also demonstrated the clear benefits of an ARB (losartan) over atenolol in combination with TDs on total ischemic stroke and atherothrombotic infarction. ${ }^{32}$ Taken together, these observations may support our results, showing that the incidence of stroke was low in the benidipine-based combination therapy for hypertension and that the incidence was lower in the benidipinethiazide regimen than in the benidipine- $\mathrm{BB}$ regimen.

Most hypertensive patients will need more than two drugs to control their hypertension. ${ }^{33}$ The guidelines for the treatment of hypertension propose that consideration should be given to starting with two drugs, ${ }^{9}$ and they recommend a $\mathrm{CCB}$ with $\mathrm{ARB}$ as the preferred combination therapy, and CCBs with diuretics as an acceptable combination therapy. ${ }^{13,14}$ However, the efficacy of these treatment regimens has not been fully proven by outcome studies. The findings of the COPE trial showed that the benidipine-thiazide regimen is more effective in preventing both hemorrhagic stroke and ischemic stroke, in addition to all types of stroke, compared with the benidipine-BB regimen.

Epidemiological study showed that no stepwise increase in risk was observed in groups treated with antihypertensive medication. ${ }^{6}$ However, this result is not consistent with those of this study. The difference of the study design between the observational study and our prospective randomized study may explain this inconsistency. In addition, diuretics were used in only approximately $1 \%$ of our study population at baseline, and after the intervention, the combination of benidipine and a TD may have reduced the incidence of hemorrhagic stroke and ischemic stroke more robustly than the other two combination therapies.

\section{Study limitations}

First, we adopted the PROBE design, and the non-blinded treatment allocation could have influenced the attitude of patients and investigators regarding compliance with the study medications or staying in the study. Second, because the sample size of this subanalysis was relatively small and the incidence of stroke was low in the benidipine-based combination therapy in the COPE trial, the optimal combination therapy for preventing stroke in hypertensive patients should be investigated in a future trial. Third, we randomly assigned one of the three classes of antihypertensive agents without any restriction regarding the drugs in each class, so we cannot deduce that the present results were caused by drug class effects, especially in the case of BBs. Finally, owing to the inherent limitations of any study, such as this trial, the finding that a CCB combined with a BB was inferior in terms of incidence of stroke in hypertensive patients should 
be confirmed or refuted by future studies, although this study is the first one to assess the CCB benidipine-based combination therapy for stroke risk.

In conclusion, this study was the first to demonstrate that the CCB benidipine combined with a TD significantly reduced not only the incidence of all types of stroke but also the incidence of both hemorrhagic stroke and ischemic stroke compared with benidipine combined with a $\mathrm{BB}$ treatment. It is possible to conclude that the CCB benidipine combined with a TD might be more beneficial for preventing stroke compared with benidipine combined with a BB.

\section{CONFLICT OF INTEREST}

All of the authors report receiving lecture fees from various pharmaceutical companies in Japan, including Kyowa Hakko Kirin, Japan.

\section{ACKNOWLEDGEMENTS}

This trial was conducted as a collaborative research between Yamaguchi University and the sponsor (Kyowa Hakko Kirin). We thank the collaborators and members of the COPE trial group. This study was supported by the Japanese Society of Hypertension. The trial registration: http://clinicaltrials.gov (identifier NCT00135551) and http://www.umin.ac.jp/ctr/index-j.htm (UMIN000001152).

1 Gardener $\mathrm{H}$, Rundek T, Wright CB, Elkind MS, Sacco RL. Dietary sodium and risk of stroke in the northern Manhattan study. Stroke 2012; 43: 1200-1205.

2 Kubo M, Kiyohara Y, Kato I, Tanizaki Y, Arima H, Tanaka K, Nakamura H, Okubo K, lida M. Trends in the incidence, mortality, and survival rate of cardiovascular disease in a Japanese community: the Hisayama study. Stroke 2003; 34: 2349-2354.

3 Miura K, Nakagawa H, Ohashi Y, Harada A, Taguri M, Kushiro T, Takahashi A, Nishinaga M, Soejima H, Ueshima H, Japan Arteriosclerosis Longitudinal Study G. Four blood pressure indexes and the risk of stroke and myocardial infarction in Japanese men and women: a meta-analysis of 16 cohort studies. Circulation 2009; 119: 1892-1898.

4 Hozawa A, Okamura T, Murakami Y, Kadowaki T, Nakamura K, Hayakawa T, Kita Y, Nakamura Y, Abbott RD, Okayama A, Ueshima H, NIPPON DATA80 Research Group. Joint impact of smoking and hypertension on cardiovascular disease and all-cause mortality in Japan: NIPPON DATA80, a 19-year follow-up. Hypertens Res 2007; 30: 1169-1175.

5 Turin TC, Kita Y, Rumana N, Nakamura Y, Takashima N, Ichikawa M, Sugihara H, Morita Y, Hirose K, Okayama A, Miura K, Ueshima H. Ischemic stroke subtypes in a Japanese population: Takashima Stroke Registry, 1988-2004. Stroke 2010; 41: 1871-1876.

6 Asayama K, Ohkubo T, Yoshida S, Suzuki K, Metoki H, Harada A, Murakami Y, Ohashi Y, Ueshima H, Imai Y, Japan Arteriosclerosis Longitudinal Study g. Stroke risk and antihypertensive drug treatment in the general population: the Japan arteriosclerosis longitudinal study. J Hypertens 2009; 27: 357-364.

7 Mancia G, Laurent S, Agabiti-Rosei E, Ambrosioni E, Burnier M, Caulfield MJ, Cifkova R, Clement D, Coca A, Dominiczak A, Erdine S, Fagard R, Farsang C, Grassi G, Haller H, Heagerty A, Kjeldsen SE, Kiowski W, Mallion JM, Manolis A, Narkiewicz K, Nilsson P, Olsen MH, Rahn KH, Redon J, Rodicio J, Ruilope L, Schmieder RE, Struijker-Boudier HA, Van Zwieten PA, Viigimaa M, Zanchetti A. Reappraisal of European guidelines on hypertension management: a European Society of Hypertension Task Force document. Blood Press 2009; 18: 308-347.

8 Chobanian AV, Bakris GL, Black HR, Cushman WC, Green LA, Izzo JL Jr., Jones DW, Materson BJ, Oparil S, Wright JT Jr., Roccella EJNational Heart L, Blood Institute Joint National Committee on Prevention DE, Treatment of High Blood P, National High Blood Pressure Education Program Coordinating C. The Seventh Report of the Joint National Committee on Prevention, Detection, Evaluation, and Treatment of High Blood Pressure: the JNC 7 report. JAMA 2003; 289: 2560-2572.

9 Ogihara T, Kikuchi K, Matsuoka H, Fujita T, Higaki J, Horiuchi M, Imai Y, Imaizumi T, Ito S, Iwao H, Kario K, Kawano Y, Kim-Mitsuyama S, Kimura G, Matsubara H, Matsuura H, Naruse M, Saito I, Shimada K, Shimamoto K, Suzuki H, Takishita S, Tanahashi N, Tsuchihashi T, Uchiyama M, Ueda S, Ueshima H, Umemura S, Ishimitsu T, Rakugi H. The Japanese Society of Hypertension Guidelines for the Management of Hypertension (JSH 2009). Hypertens Res 2009; 32: 3-107.

10 Kubo M, Kiyohara Y, Ninomiya T, Tanizaki Y, Yonemoto K, Doi Y, Hata J, Oishi Y, Shikata K, lida M. Decreasing incidence of lacunar vs other types of cerebral infarction in a Japanese population. Neurology 2006; 66: 1539-1544.
11 Staessen JA, Li Y, Thijs L, Wang JG. Blood pressure reduction and cardiovascular prevention: an update including the 2003-2004 secondary prevention trials. Hypertens Res 2005; 28: 385-407.

12 Neal B, MacMahon S, Chapman N. Effects of ACE inhibitors, calcium antagonists, and other blood-pressure-lowering drugs: results of prospectively designed overviews of randomised trials. Blood Pressure Lowering Treatment Trialists' Collaboration. Lancet 2000; 356: 1955-1964.

13 Gradman AH, Basile JN, Carter BL, Bakris GL, American Society of Hypertension Writing G.. Combination therapy in hypertension. J Clin Hypertens (Greenwich) 2011; 13: $146-154$.

14 Sever PS, Messerli FH. Hypertension management 2011: optimal combination therapy. Eur Heart J 2011; 32: 2499-2506.

15 Yao K, Nagashima K, Miki H. Pharmacological, pharmacokinetic, and clinical properties of benidipine hydrochloride, a novel, long-acting calcium channel blocker. J Pharmacol Sci 2006; 100: 243-261.

16 Ogihara T, Matsuzaki M, Matsuoka H, Shimamoto K, Shimada K, Rakugi H, Umemoto S, Kamiya A, Suzuki N, Kumagai H, Ohashi Y, Takishita S, Abe K, Saruta T. The combination therapy of hypertension to prevent cardiovascular events (COPE) trial: rationale and design. Hypertens Res 2005; 28: 331-338.

17 Matsuzaki M, Ogihara T, Umemoto $S$, Rakugi $H$, Matsuoka $H$, Shimada $K$, Abe $K$, Suzuki N, Eto T, Higaki J, Ito S, Kamiya A, Kikuchi K, Suzuki H, Tei C, Ohashi Y, Saruta T, Combination Therapy of Hypertension to Prevent Cardiovascular Events Trial G. Prevention of cardiovascular events with calcium channel blocker-based combination therapies in patients with hypertension: a randomized controlled trial. J Hypertens 2011; 29: 1649-1659.

18 Ogihara T, Matsuzaki M, Umemoto S, Rakugi H, Matsuoka H, Shimada K, Higaki J, Ito S, Kamiya A, Suzuki H, Ohashi Y, Shimamoto K, Saruta T, Combination Therapy of Hypertension to Prevent Cardiovascular Events Trial G. Combination therapy for hypertension in the elderly: a sub-analysis of the Combination Therapy of Hypertension to Prevent Cardiovascular Events (COPE) Trial. Hypertens Res 2012; 35: 441-448.

19 Stroke-1989. Recommendations on stroke prevention, diagnosis, and therapy. Report of the WHO Task Force on Stroke and other Cerebrovascular Disorders. Stroke 1989; 20: $1407-1431$.

20 Adams HP Jr., Bendixen BH, Kappelle LJ, Biller J, Love BB, Gordon DL, Marsh EE 3rd. Classification of subtype of acute ischemic stroke. Definitions for use in a multicenter clinical trial. TOAST. Trial of Org 10172 in Acute Stroke Treatment. Stroke 1993; 24: 35-41.

21 Lindholm LH, Carlberg B, Samuelsson O. Should beta blockers remain first choice in the treatment of primary hypertension? A meta-analysis. Lancet 2005; 366: 1545-1553

22 Hayashi K, Homma K, Wakino S, Tokuyama H, Sugano N, Saruta T, Itoh H. T-type Ca channel blockade as a determinant of kidney protection. Keio J Med 2010; 59: 84-95.

23 Hayashi K. L-/T-type Ca channel blockers for kidney protection: ready for sophisticated use of Ca channel blockers. Hypertens Res 2011; 34: 910-912.

24 Abe M, Okada K, Maruyama N, Matsumoto S, Maruyama T, Fujita T, Matsumoto K, Soma M. Benidipine reduces albuminuria and plasma aldosterone in mild-to-moderate stage chronic kidney disease with albuminuria. Hypertens Res 2011; 34: 268-273.

25 Kosaka H, Hirayama K, Yoda N, Sasaki K, Kitayama T, Kusaka H, Matsubara M. The L-, $\mathrm{N}$-, and T-type triple calcium channel blocker benidipine acts as an antagonist of mineralocorticoid receptor, a member of nuclear receptor family. Eur J Pharmacol 2010; 635: 49-55.

26 Fuji Y, Suzuki H, Katsumata H, Nakajima S, Saruta T. Hormonal and renal responses to oral once-daily calcium entry blocker in normotensive and hypertensive persons. J Cardiovasc Pharmacol 1988; 11: 438-443.

27 Sica DA. Current concepts of pharmacotherapy in hypertension: thiazide-type diuretics: ongoing considerations on mechanism of action. J Clin Hypertens (Greenwich) 2004; 6: 661-664.

28 Webb AJ, Rothwell PM. Effect of dose and combination of antihypertensives on interindividual blood pressure variability: a systematic review. Stroke 2011; 42: 2860-2865.

29 Rothwell PM. Limitations of the usual blood-pressure hypothesis and importance of variability, instability, and episodic hypertension. Lancet 2010; 375: 938-948.

30 Webb AJ, Fischer U, Mehta Z, Rothwell PM. Effects of antihypertensive-drug class on interindividual variation in blood pressure and risk of stroke: a systematic review and meta-analysis. Lancet 2010; 375: 906-915.

31 Williams B, Lacy PS, Thom SM, Cruickshank K, Stanton A, Collier D, Hughes AD, Thurston H, O'Rourke MInvestigators C, Anglo-Scandinavian Cardiac Outcomes Trial I, Committee CS, Writing C. Differential impact of blood pressure-lowering drugs on central aortic pressure and clinical outcomes: principal results of the Conduit Artery Function Evaluation (CAFE) study. Circulation 2006; 113: 1213-1225.

32 Dahlof B, Devereux RB, Kjeldsen SE, Julius S, Beevers G, de Faire U, Fyhrquist F, Ibsen H, Kristiansson K, Lederballe-Pedersen O, Lindholm LH, Nieminen MS, Omvik P, Oparil S, Wedel H, Group LS. Cardiovascular morbidity and mortality in the Losartan Intervention For Endpoint reduction in hypertension study (LIFE): a randomised trial against atenolol. Lancet 2002; 359: 995-1003.

33 Bakris GL. Maximizing cardiorenal benefit in the management of hypertension: achieve blood pressure goals. J Clin Hypertens 1999; 1: 141-147. 


\section{APPENDIX}

Appendix Combination Therapy of Hypertension to Prevent Cardiovascular Events Trial Group

Principal Study Coordinator-T Ogihara.

Study Adviser-T Saruta.

Steering Committee-M Matsuzaki (Chairperson), T Eto, T Fujita,

J Higaki, S Ito, A Kamiya, K Kikuchi, H Matsuoka, H Suzuki, C Tei.

Protocol Committee-H Matsuoka (Chairperson), H Kumagai,

Y Ohashi, H Rakugi, K Shimamoto, S Takishita, S Umemoto.

Endpoint Classification Committee-K Shimada (Chairperson), K Hayashi, K Kario, M Kawana, K Kitagawa, H Makino, M Matsumoto, J Yoshikawa.

Independent Data Monitoring Committee-K Abe (Chairperson),

H Matsuura, Y Ohashi, K Otsuka, K Tanabe.

Safety Committee-N Suzuki (Chairperson), S Nogawa, K Utsunomiya, T Yoshikawa, W Yumura.

Study Statistician-Y Ohashi.

Coordinating Center-S Umemoto (EBM Office, Center for Clinical Research, Yamaguchi University Hospital).

\section{INVESTIGATORS:}

HOKKAIDO DISTRICT_K Kikuchi, N Hasebe, M Bunya, W Fujii, N Funayama, M Gima, K Hashizume, Y Hirayama, H Matsuhashi, $\mathrm{H}$ Morimoto, $\mathrm{T}$ Myojo, $\mathrm{K}$ Ohori, $\mathrm{H}$ Omiya, $\mathrm{T}$ Ota, A Sato, T Shiokoshi, H Tanaka, K Yamazaki, H Yoshie, K Shimamoto, M Abiru, M Adachi, Y Fujise, K Hanawa, K Ishii, Y Kadono, T Kaku, S Kaneta, M Kato, N Kato, H Kobayashi, T Komakine, T Matsumoto, T Mita, N Miura, H Mukai, K Nagao, H Nakagawa, M Nakagawa, $\mathrm{N}$ Nakajima, $\mathrm{T}$ Nishimiya, Y Nishino, A Nunokawa, J Ohata, H Ooiwa, R Sato, S Satoh, S Shibata, M Takada, Y Takagawa, Y Takagi, S Takeichi, S Tanaka, N Togashi, N Ura, C Wakabayashi, D Yoshida, H Yoshida, K Yoshida, A Kitabatake, H Tsutsui, M Akutsu, S Fujii, T Furumoto, S Kakinoki, H Kawasaki, T Kimura, M Makiguchi, H Matsuo, H Okamoto, Y Oyama, J Shimokawa, N Tsuzuki.

TOHOKU DISTRICT - S Ito, Y Imai, R Domon, H Ebina, S Egawa, T Haruyama, H Hashimoto, T Hayakawa, H Inomata, Y Katahira, T Katakura, R Kikuchi, H Kimura, S Kyogoku, Y Kyogoku, K Matsuo, H Nakazawa, H Odakura, F Okuguchi, E Ohtomo, H Ouchi, M Seino, M Tadokoro, Y Tanno, N Uchida, T Yamanaka, K Yunomura, K Okumura, T Hatayama, Y Kanehira, H Kaneko, M Kimura, N Maeda, A Mikuniya, H Narita, M Ono, T Osanai, M Sato.

TOKYO DISTRICT - H Yoshino, S Momomura, M Ono, M Inoue, T Iwase, K Miyazaki, M Taki, T Aizawa, Y Hasunuma, H Makino, H Okabayashi, S Hosoda, T Sumiyoshi, M Abe, Y Kira, M Nagayama, K Sakai, O Yoshikawa, M Ide, N Kimura, S Matsuzaka, Y Miyajima, K Sawai, T Sumi, R Takada, M Toma, Y Yamada, K Yoda, T Yokokawa, $\mathrm{S}$ Yokoyama, K Kanmatsuse, $\mathrm{T}$ Kushiro, $\mathrm{T}$ Anazawa, $\mathrm{T}$ Ebuchi, H Fujita, N Katsumata, K Masubuchi, T Migita, T Osada, Y Otsuka, F Saito, S Shimoda, K Sugino, A Takahashi, S Tani, K Yumi, H Daida, T Arino, T Iesaki, Y Inomata, H Nakahara, H Shiraishi, H Sudo, $\mathrm{T}$ Degawa, T Araki, H Itaya, H Komatsu, H Kuwana, T Mikawa, H Nomoto, N Ogawa, H Sato, H Takase, H Toyoda, M Yamamoto, K Obayashi, I Akabane, H Hamamoto, $\mathrm{R}$ Kanbara, $\mathrm{H}$ Kato, H Kimura, N Mori, K Yamada, M Yamamuro, M Isobe, H Emoto, $\mathrm{O}$ Inaba, $\mathrm{T}$ Inazawa, $\mathrm{H}$ Inomata, $\mathrm{K}$ Isobe, $\mathrm{Y}$ Ito, $\mathrm{M}$ Komura, H Kosuge, Y Maejima, N Miwa, T Nishimori, K Otomo, K Sakurai, M Sawada, M Seya, M Shimizu, T Takagi, M Tamura, K Tanaka, D Tezuka, T Tokunaga, A Yagishita, A Yamashina, T Hara, S Hayashi, Y Hirayama, Y Hirooka, M litaka, T Ishiyama, F Kijima, H Kobayashi, Y Kobayashi, K Kondo, T Kuwabara, M Mugishima, Y Nakayama, Y Nishizato, Y Osamura, Y Sakomura, S Saneshige, N Shindo,
$\mathrm{N}$ Takao, Y Takata, $\mathrm{H}$ Tomiyama, S Ishimaru, Y Obitsu, H Shigematsu, T Baba, H Fukushima, T Hirayama, K Magari, S Makimura, T Nagae, K Osada, T Osada, T Shimizu, H Suesada, K Tamura, T Yamazaki, A Hirai, T Fukasawa, H Ono, M Yamakado, T Shiba, S Otomi, A Uehata, K Takazawa, A Aizawa, T Iketani, M Kino, H Kobayashi, T Morishima, N Sakamoto, T Sakamoto, $\mathrm{H}$ Yamakawa, H Kasanuki, R Nagai, T Kadowaki, J Tanaka, T Yamazaki, M Takagi, S Ui, S Baba, K Fujita, T Hasegawa, K Tajima, M Tanaka, N Yamato, I Kuwajima, K Harada, H Miyata, S Mizuno, S Ueda, K Sugi, H Ando, K Mishima, M Moroi, S Nishizawa, S Suzuki, J Yamazaki, R Nakanishi, H Nakano, K Tokuyasu, T Aoyagi, M Fujioka, N Kobayakawa, K Nakajima, A Hirayama, K Tsukamoto, Y Araki, H Hara, K Hara, T Saruya.

KANAGAWA DISTRICT-S Umemura, $\mathrm{M}$ Arima, $\mathrm{T}$ Endo, K Furumi, Y Hatori, Y Ikeda, Y Ikeya, T Kaneda, T Kawada, $\mathrm{T}$ Kawano, $\mathrm{T}$ Kawashima, $\mathrm{M}$ Kihara, $\mathrm{M}$ Kikuta, A Kitamura, H Kobayashi, S Kobayashi, T Kuji, S Masuda, Y Minamimoto, K Minamisawa, T Mitsuhashi, N Miyazaki, Z Nagashima, T Nakatogawa, R Nakayama, N Nyui, M Ogawa, T Onishi, K Saka, T Sano, A Sato, K Shiba, F Shionoiri, H Sugiyama, H Suzuki, I Takasaki, K Tamura, Y Tokita, M Umemura, S Yamaguchi, G Yasuda.

CHIBA-SAITAMA DISTRICT-S Nakamura, K Takayanagi, T Hayashi, M Ichihara, S Kobayashi, Y Sakai, T Uchida, I Yaguchi, I Komuro, S Aoki, Y Hashimoto, C Ibuki, Y Isobe, R Kumasaka, M Matsuda, K Mizuno, D Murakami, S Nakamura, M Nakatani, T Ohba, T Ohara, T Okumura, A Saito, T Sakurai, S Sato, W Sato, K Seimiya, Y Seino, K Shimizu, M Takano, K Tokuyama, D Uchida, $\mathrm{K}$ Yodogawa.

KITAKANTO-KOSHINETSU DISTRICT_S Oshima, M Kurabayashi, $\mathrm{N}$ Baba, Y Furushima, T Goto, T Hosoi, T Iijima, K Ito, Y Iwata, H Kubo, M Matsumoto, M Miyazaki, F Naganuma, K Nakada, M Tokushima, K Tsunoda, S Wakamatsu, Y Yagihara, Y Aizawa, M Aizawa, M Aizawa, N Hayashi, T Hori, H Kobayashi, M Kodama, K Maeda, K Miura, K Okada, Y Okura, Y Sasagawa, S Takizawa, M Tamura, T Yamamoto.

TOKAI DISTRICT_-T Murohara, Y Awaji, H Funahashi, D Hayashi, M Iida, D Ishihara, S Ishikawa, S Kamide, M Kanashiro, N Kurebayashi, S Kyo, H Matsui, K Matsuo, M Morishima, H Noda, T Noda, N Okumura, T Ota, S Shimizu, F Somura, Y Takada, Y Takeichi, $\mathrm{H}$ Takezawa, $\mathrm{T}$ Uchikawa, D Yoshikawa, G Kimura, Y Ando, M Hoshiai, N Okuda, S Suzuki, K Takada, N Takada, K Yamada, H Hishida, T Furuta, H Hayashi, K Ito, K Kato, M Nomura, T Ota, M Ohtsuki, T Tabata, S Taga, R Tateishi, T Ito, M Fukuda, T Iwa, Y Wakida, T Yonemoto, M Watarai, M Ito, H Kawai, Y Murata, S Nomoto, K Takemoto, N Tsuboi, Y Yoshida, N Inoue, M Ishikawa, M Matsumoto, T Muramatsu, R Yoshida, M Ono, Y Hanaki, H Sano, Y Shibata, K Sakai, M Ajioka, H Asano, R Okamoto, H Osanai, Y Uemura, K Yokoi, $\mathrm{T}$ Tanaka, $\mathrm{H}$ Kamiya, K Miki, M Niwa, H Fujiwara, S Minatoguchi, T Arai, S Kato, H Kobayashi, T Minagawa, N Mori, K Nakahara, Y Shimizu, M Tadokoro, N Takahashi, T Shigemasa, I Kobayashi, T Nakano, M Ito, A Fukui, Y Higashi, T Ito, U Kano, K Makino, K Nakai, M Nakajima, T Nakajima, K Sekoguchi, T Tanaka, T Tanigawa.

HOKURIKU DISTRICT—N Takekoshi, H Enyama, T Hirakawa, J Ito, T Ito, H Kakuda, T Kigoshi, K Kondo, K Masuya, M Matoba, A Nakagawa, $\mathrm{T}$ Nakahashi, $\mathrm{H}$ Nakato, H Okada, M Okuro, Y Takeuchi, H Tsugawa, T Urata, M Yasuhara, M Shimizu, H Ino, T Araki, N Fujino, T Haraki, K Hayashi, S Hifumi, T Konno, M Minamoto, S Miyamoto, M Mori, C Nakanishi, Y Sakamoto, K Sakata, S Takeda, K Ueda, K Uchiyama, S Takata, S Kaneko, I Aburadani, I Inoki, K Kitano, D Kobayashi, K Kontani, M Maekawa, 
M Maruyama, K Matsunuma, Y Nagai, Y Nagata, M Okajima, K Otowa, Y Sekiguchi, K Shinmura, S Usui, H Yokoyama, M Yonejima.

KINKI DISTRICT - K Nakao, N Hiraiwa, T Ko, I Masuda, T Nagae, K Nishino, M Sakamoto, T Kita, Y Nakagawa, T Kimura, T Doi, H Horiuchi, M Kinoshita, M Mizuno, M Ohnishi, K Shigemoto, A Wada, $T$ Yamada, $H$ Yoshida, M Nakagawa, H Matsubara, K Furukawa, T Hatta, A Inoue, H Katsume, A Masui, S Matsumoto, T Seki, K Takeda, Y Taniguchi, H Tsuji, Y Saito, Y Fukuoka, M Iwano, T Katsuyama, A Nakatani, Y Sakaguchi, T Konishi, T Izumi, I Toda, A Kamimoto, Y Nagai, E Matsuwaka, R Matsuwaka, K Takei, R Ueda, N Wakaki, T Iwasaka, H Hamada, S Hamada, H Koga, H Koito, K Kono, H Kurihara, J Maeda, S Morimoto, Y Takayama, T Aoyama, M Imai, $\mathrm{T}$ Ii, S Kashii, M Maenaka, H Ohashi, T Suyama, M Matsuda, Y Aoyagi, K Kunisada, $\mathrm{T}$ Mori, $\mathrm{T}$ Mori, J Uemura, $\mathrm{Y}$ Yokoi, $\mathrm{N}$ Morioka, $\mathrm{T}$ Ozaki, K Kanamasa, K Ishikawa, S Miyazaki, S Arima, T Kai, A Kurooka, I Shimada, M Takewa, M Taniguchi, R Hattori, K Haba, R Yokota, $\mathrm{H}$ Matsui, $\mathrm{E}$ Tone, $\mathrm{H}$ Yamahira, $\mathrm{T}$ Kawarabayashi, $\mathrm{H}$ Inaba, Y Sakaguchi, Y Yamamoto, $\mathrm{H}$ Ito, $\mathrm{M}$ Date, M Dodo, K Fujii, M Imai, K Inoue, Y Kanoh, N Komura, S Senpuku, M Takeda, H Tateyama, K Yasui, R Yoneda, H Morita, M Kawanami, A Tahara, T Sado, T Takamura, M Taniwa, Y Kitaura, M Fukuda, H Hanada, K Nakamura, K Sawada, M Yamaguchi, K Kodama, T Higo, A Hirata, M Kanzaki, S Komatsu, K Matsuo, T Murakawa, H Nakanishi, T Nemoto, M Nishio, $\mathrm{N}$ Ogasawara, Y Okuyama, Y Ueda, M Imanishi, Y Kitamura, T Sakakibara, H Yoshida, H Yoshimi, T Ogihara, H Rakugi, M Akiyama, Y Ikuno, N Imai, Y Imamura, T Inoyama, K Kamide, K Katahira, S Katsuya, T Katsuya, Y Kurokawa, O Matsuki, M Matsuo, T Nakamura, E Ogura, M Ohishi, R Sasaki, K Sugimoto, J Tachi, H Tanaka, H Tanaka, T Tsunetoshi, M Yoshino, M Hori, N Awata, T Fukukawa, Y Iimori, S Iwamoto, K Sawami, M Okamura, Y Kanayama, F Nagano, H Nakayama, H Suzuki, T Amano, K Tachibana, Y Arita, M Kirino, K Sakuyama, M Shukawa, Y Nishida, T Sakamoto, S Yanagi, K Hirota, T Majima, T Ota, T Tanaka, R Nohara, T Funauchi, O Isogai, S Takashima, H Koike, M Nishimoto, Y Kawase, O Tojo, Y Chimori, H Harada, H Takeoka, S Kishi, M Yokoyama, K Hirata, J Ejiri, R Emoto, Y Furuta, K Hattori, R Kuroda, N Maehashi, H Monnaka, Y Ohashi, T Okada, H Suzuki, M Takeuchi, M Ohyanagi, M Masai, T Masuyama, M Kawabata, T Kajiya, N Daito, T Fujisawa, S Fujita, M Hasegawa, M Hirakoba, $\mathrm{T}$ Hirano, Y Ikeda, $\mathrm{N}$ Imai, $\mathrm{K}$ Marumoto, S Masuda, $\mathrm{T}$ Miki, M Mitsunaga, H Mitsuoka, Y Miyachi, N Mukohara, T Nagao, K Nakada, K Nishian, S Nishioka, T Ogura, Y Onishi, K Sakaguchi, I Sano, W Sano, M Shigenobu, A Tabuchi, J Takashima, Y Taniguchi, H Uchida, T Ueda, N Urabe.
CHUGOKU DISTRICT-H Makino, S Harada, S Hirakawa, H Hirata, J Ishii, K Koten, Y Nagake, T Nakajima, Y Nakamura, T Terami, K Mitsudo, M Fujii, K Fujita, E Iwano, K Kadota, Y Nishihara, Y Takaya, H Yamamoto, T Yamamoto, C Shigemasa, I Hisatome, T Kato, H Miyakoda, M Sakamoto, M Shimoyama, T Shimada, K Tanabe, Y Goto, Y Hanada, K Kawakami, J Kitamura, K Kitamura, H Nakata, N Oyake, H Sugiura, H Tsukihashi, M Matsuzaki, S Umemoto, S Aoyagi, H Aoyama, T Fujino, S Fukuta, $\mathrm{N}$ Hiroyama, Y Ikeda, Y Inamoto, R Kametani, A Kamiya, Y Kanamaru, S Kotoku, A Matsushima, J Morita, Y Murano, M Nakatsuka, S Nishimura, Y Nisnimura, T Okamura, F Okuda, U Onaka, M Ozaki, A Shimizu, C Takata, M Tamitani, T Watada, T Watada, K Yamamoto, M Yamauchi, T Yorozu, H Yoshikane, F Yoshino.

SHIKOKU DISTRICT-J Higaki, J Doiuchi, T Fukuoka, $\mathrm{H}$ Hashimoto, $\mathrm{M}$ Igase, $\mathrm{H}$ Kadota, $\mathrm{H}$ Kaneko, S Komatsu, Y Matsubara, K Miyoshi, K Murakami, S Murao, T Niiya, T Ochi, A Satoh, T Seki, H Takahashi, T Yamashita, T Yoshino, M Kohno, N Fujita, T Fukui, T Hamamoto, K Hasegawa, H Hitomi, K Ihara, H Kiyomoto, H Masugata, I Matsumoto, N Takahashi, K Yoshikawa, Y Doi, M Arisawa, T Egawa, M Fukuda, Y Kawada, H Kusunose, T Maeda, N Minami, M Nishinaga, T Noguchi, K Okabayashi, K Sato, T Satomi, J Takada, S Tamura, T Usui, M Yamada, M Irahara, H Azuma, M Fujimura, H Fujino, M Fujino, E Harada, S Harada, Y Hiasa, S Hosokawa, K Kawahara, K Koshiba, M Murakami, Y Nakaya, H Nii, S Nozaki, A Ota, T Ozaki, K Sone, Y Tsutsui, $S$ Ueta.

KYUSHU DISTRICT-M Nobuyoshi, Y Fujishima, K Hisano, $\mathrm{H}$ Ikezono, $\mathrm{R}$ Imawatari, $\mathrm{Y}$ Izumi, $\mathrm{H}$ Kanai, $\mathrm{T}$ Nakamura, T Nakamura, T Noda, E Ono, S Tanaka, T Tsuiki, $\mathrm{T}$ Yanai, T Sasaguri, S Akimitsu, K Dohmen, K Fujisawa, K Fukuyo, S Harashima, T Hayashi, M Hirata, Y Hirata, N Ikeda, H Ikematsu, W Ikematsu, W Kajiyama, Y Kawakami, I Kawasaki, H Kondo, H Kusuhara, N Maeda, H Miyahara, A Motomura, K Nakamura, T Noguchi, T Okinaga, M Sato, I Shimada, H Shin, K Soejima, K Sugi, T Taniguchi, T Uwatoku, S Yamaga, K Yamaji, J Yanagi, H Yano, K Saku, M Enomoto, T Hiratsuka, K Imoto, R Kamei, H Kanaya, M Kohara, M Kusuda, H Nishikawa, H Sako, $\mathrm{T}$ Imaizumi, K Yano, K Maemura, $\mathrm{N}$ Ashizawa, M Hazama, Y Ishida, T Ito, M Kanda, M Kimura, T Noguchi, Y Oku, S Seto, S Suzuki, H Ogawa, K Goto, K Honjio, Y Horio, H Jinnouchi, Y Kaku, S Kawano, T Kimura, Y Kiyohara, A Maki, N Matsumoto, K Misumi, T Sakamoto, K Sasaki, S Sugiyama, E Tanaka, S Uemura, C Tei, K Arima, Y Daitoku, H Eto, T Hashino, K Ichinari, Y Ikeda, A Iriki, K Kiyonaga, K Kubota, Y Makise, S Masuzaki, M Miyata, H Mizoguchi, T Niiyama, Y Samejima, S Yonezawa. 